\title{
Exercise Box Jump to Increase the Strength of Long Passes and Shots
}

\author{
Fadli Suardhana Eka Putra \\ Master Program in Sport Science \\ Universitas Negeri Yogyakarta \\ Yogyakarta, Indonesia \\ fadli.suardhana@gmail.com
}

\author{
Hari Amirullah Rachman \\ Faculty of Sport Science \\ Universitas Negeri Yogyakarta \\ Yogyakarta, Indonesia \\ harirachman@yahoo.com.au
}

\begin{abstract}
- the purpose of this research was to evaluate the training with the box jump method in improving the soaring kick for high school students in Indonesia, especially in the East Kalimantan province. This research was an experimental study of one group with a pretest-posttest design. The research population took one of 40 high school students using the random sampling of the total population. Data analysis technique used statistical tests. The result of preliminary data analysis on pretest obtained total score of 54, whereas after being treated by the box jump method, the posttest obtained total score of 91 . The research took 40 samples who were given the box jump training which obtained $F_{\text {count }}=8.791$ and by using $d k=39$ and $\alpha=0.05$ so obtained $F_{\text {table }}=1.685$. Hence, $F_{\text {count }}>F_{\text {table. }}$ These results indicate an increase in the soaring kick by samples that have been tested. Based on the results of the calculations, it can be concluded that there is a significant $37 \%$ increase after treatment with the box jump training method.
\end{abstract}

\section{Keywords—box jump, long pass, football}

\section{INTRODUCTION}

Football is a very popular sport in the world. Playing this sport requires good skills and techniques. Today, adults do not only play modern football but children up to adolescents also play this game. Now, the football game has entered the curriculum of physical education in schools. It means that students can develop abilities not only outside the school, but also inside schools through extracurricular activities. The football game consists of several basic techniques of kicking, controlling, dribbling, heading, and passing. Of the various basic techniques above, the passing technique is the most common thing performed in this game. The basis for playing good football is a good passing ability [1]. The technique of kicking is divided into two namely horizontal kick and the soaring kick. Most mistakes are commonly incurred when students attempt the soaring kick. The muscle strength their leg is not maximal, so, the ball does not soar as it is supposed to. Hence, students have difficulties when performing the soaring kick, soaring shot, and sweeping the ball from the defense area near the goal area itself. Intelligence in managing trainings, aspects of training, development of other supporting factors in soccer training, such as physical factors, techniques, tactics, mental and champion maturity is needed. In order for such condition to remain stable, players must have the awareness and discipline when running the portion of training that has been given by the coach and have a strong will and decdication to improve performance by increasing the portion of the exercise itself. Good physical support improves an athlete's performance if the program is delivered according to the expected needs. In a football game, a long-range soaring kick can be more precisely produced using an inner foot, as it produces a parabolic ball kick stretching the distance further with a good kicking accuracy. The technique of performing the soaring kick requires good accuracy to enable the ball reach the intended point as it does when giving a soaring pass to a friend who requires a distance of approximately 30 to 40 meters and when doing long distance shooting in front of an opponent's goal. Increasing the muscle strength of the leg can be done with many training methods, one of which is a plyometic training that supports the training program. The Plyometric training is generally regarded as a jump exercise; it aims to activate the muscles involved to achieve maximum strength in the shortest time in concentric or eccentric way [2]. Plyometric training (PT) is an explosive weight category with resistance training that focuses on exploiting the additional output power from the muscle stretch reflex to increase speed and strength. A period of rapid concentric contraction in muscle after rapid eccentric elongation of the muscle fibers under the load increases the strength produced by muscle [3]. Regardless of running, jumping, and changing direction, the explosive training can also be beneficial to other soccer-specific athletic requirements such as kicking a ball or endurance [4]. The plyometric training that can be given here is the plyometric box jump training as it is able to provide explosive movement of leg muscles needed to obtain a great force. This research would like to prove that there is an increase in soarcing kicks in one of the high schools in East Kalimantan, Indonesia..

\section{METHODS}

This research was a pre experimental design, with one group pretest-posttest design. The sample of the research studied high school students in one of the high schools in East Kalimantan, Indonesia with 40 people from the total population of 240 students. The sampling was done by the random sampling technique without considering the strata of the population. The implementation was done for 6 weeks with 3 meetings a week. Tests and measurements were performed twice in pre-test and final test (post test). The instrument of this research measured soaring kicks using the soaring kicking assessment chart of Danny Mielke, 
(2007: 26). The test for the soaring kick was done 3 times and the best score was taken as the initial score (pre-test) and the score (post-test). Details of the assessment are as follows:

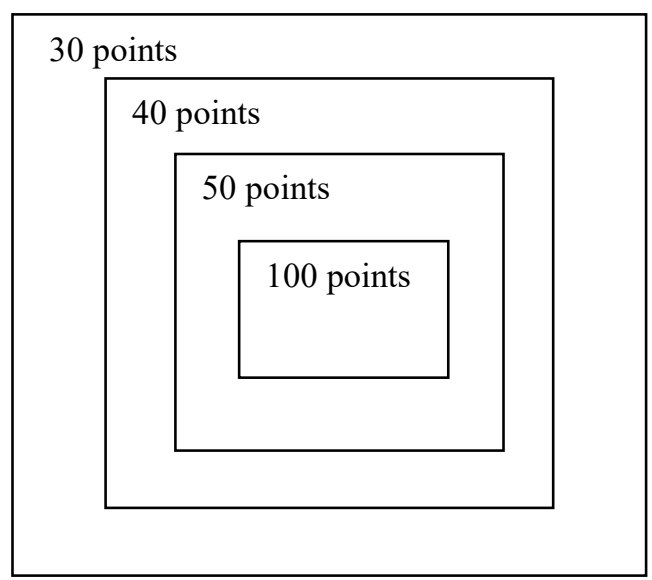

Notes:

100 Points $=4$ Scores, 50 Points $=3$ Scores, 40 Points $=2$ Scores, 30 Points $=1$ Score

Fig. 1. Assessment scoring

To know the influence of plyometric box jump training to the result of soaring kicks, this research used simple linear regression equation formula with the following formula:

$$
\mathrm{Y}=\mathrm{a}+\mathrm{bX}
$$

Notes:

$$
\begin{aligned}
\mathrm{Y} & : \text { The result of soaring kick } \\
\mathrm{X} & : \text { Plyometric Box jump training } \\
\mathrm{a}: & \text { The value of the constant of price } \mathrm{Y} \text { if } \mathrm{X}=0 \\
\mathrm{~b}: & \text { The value of the direction as a predictor of } \\
& \text { prediction that shows the value of increase } \\
& (+) \text { or decrease }(-) \text { of variable } \mathrm{Y} .
\end{aligned}
$$

After the data were obtained, the data were processed with the above statistic formula and F-test was performed. If $F_{\text {count }}>F_{\text {table }}$ it means there is an influence when using the box jump training method to increase the result of soaring kick.

\section{RESULT AND DISCUSSION}

TABLE I. THE DIFFERENCES OF MEAN

\begin{tabular}{|c|c|c|}
\hline Groups & Mean & Percentage \\
\hline Pre-test & 54 & $37 \%$ \\
\hline Post-test & 91 & \\
\hline
\end{tabular}

From the results of research using 40 samples who were given box jump training, the $F_{\text {count }}=8,791$ and by applying $\mathrm{dk}=39$ and $\alpha=0.05$ the $\mathrm{F}_{\text {table }} 1,685$. That is why $\mathrm{F}_{\text {count }}>$

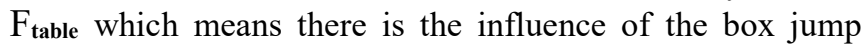
training on the results of the soaring kick. Based on the results of the calculation, the authors obtained regression equation of $\mathrm{Y}=1.254+0.459(\mathrm{X})$. This regression equation is derived from the calculation of a simple linear regression equation between a box jump training on the result of a soaring kick as a $\mathrm{Y}$ variable. The regression equation is to predict the upcoming state and also to find out the increase if $\mathrm{X}$ changes. Thus a simple linear regression of $\mathrm{Y}$ over $\mathrm{X}$ has a significant influence.

Modern football now is highly dependent on the technical skills that every player in the field has. Having power in doing soaring kicks is helpful in the game. During an attack, the player can maximize his leg muscle strength to perform long-distance shooting with precise accuracy. In the event of starting the attack, the player can maximize the ability of his leg muscles by performing various passes, such as short passing and also long soaring passing directed to teammates in order to facilitate the movement in goalscoring and in a defensive position, the player can maximize keeping the ball off their own goal area. The situation of the dead ball can also be maximized to score goals ranging from corner kicks or in situations when taking a free kick in front of an opponent's goal, strength and accuracy in throwing the ball also influences the final result. Most coaches have been influenced at a greater or lesser extent, by tactics called "long ball games" or "direct play," which is a tactic used as a consequence of this research [5]. In fact, coaches often use direct play strategies during the game.

Judging from the data calculated using the F-test, the result proves that $F_{\text {count }}=8.791>F_{\text {table }}=1.685$ which means that there is a significant increase or the influential one in the results of soaring kick kicks.

The plyometric box jump training is one of the most commonly used methods for increasing the strength of the leg muscle. The training method of the box jump is also a form of training that emphasizes on the length and frequency of steps. Implementation of the box jump training concerns a lot about the intensity and load which are provided by controlling the course of training such as taking into account the height of the box used, and the distance to be traveled along with the load used

\section{CONCLUSION}

From the research above, it can be concluded that using the plyometric box jump training method gives a significant improvement to the strength of the long soaring kick as well as adding good kick accuracy for high school students in East Kalimantan, Indonesia. This is evidenced by the result of $\mathrm{F}_{\text {count }}>\mathrm{F}_{\text {table. }}$ It is expected that the research can be used as a reference for coaches and teachers who can improve students' physical condition by using the plyometric box jump method in school extracurricular activities. 


\section{REFERENCES}

[1] B. J. Wallace, "Quantification of vertical ground reaction forces of popular bilateral plyometric exercise," Journal of Strength and Conditioning Research, 2010. vol. 24, pp. 207-212.

[2] M. A. Booth, Rhonda, "Effects of plyometric training on sport performance," Strength and Conditioning Journal, 2016, vol. 30, pp 30-37.

[3] R. R. Campilo, "Effects high intensity plyometric training on explosive action and endurance of young," Journal of Strength and Conditioning Research, 2014. vol. 28, pp. 1335-1342.

[4] K. Burcak, "The effects on soccer passing skills when warming up with two different sized soccer balls," Department of Physical Education and Sport Teaching, 2015, vol. 10, pp. 2860-2868.

[5] M. Hughes, I. Franks, "Analysis of passing sequences, shots and goals in soccer," Journal of Sports Sciences, 2014, pp. 509-514.

[6] Sugiyono, "Statistika Untuk Penelitian". Bandung, Alfabeta, 2014).

[7] B. O. Tudor, "Periodization of strengh the new wave in strengh training”. Toronto, Ontario Canada, Orienta Calcina, 1993.

[8] D. Mielke, "Dasar-Dasar Sepakbola". Bandung, Pakar Raya, 2007. 